\title{
ESTIMATION OF STATURE FROM FOOT DIMENSIONS OF SCHOOL AGE GROUP CHILDREN IN MAHARASHTRA STATE
}

\author{
CHAVAN L.N. ${ }^{*}$, GEETHA K.N. ${ }^{1}$, KARUNA KATTI² AND SHINDE C.D. ${ }^{1}$ \\ ${ }^{1}$ MGM Medical College, Navi Mumbai, Maharashtra, India. \\ ${ }^{2}$ SGT Medical College, Gurgaon, Haryana, India. \\ *Corresponding Author: Email- geetha.dr@gmail.com
}

Received: January 14, 2012; Accepted: February 15, 2012

\begin{abstract}
The present study is based on measurement of foot length of 200 students of two age groups - 6 to $8 \mathrm{yr} \& 12$ to14 yr. Foot length (heel to tip of each digit), foot width, foot girth at metatarsophalangeal joints \& stature were the parameters. Collected data was analyzed. Standard deviation, co-relation coefficient, sexual dimorphism, regression formulae and multiple regression equations were predicted.

This study suggest a significant relationship between the foot dimensions \& stature. If either of the measurement is known, the other can be predicted. This would be useful for anthropologist and forensic medicine experts.

Key words- Foot dimensions, foot length, foot width, foot girth, stature, correlation coefficient, regression equation, anthropology, sexual dimorphism
\end{abstract}

Citation: Chavan L.N., et al. (2012) Estimation of Stature from Foot Dimensions of School Age Group Children in Maharashtra State. International Journal of Medical and Clinical Research, ISSN:0976-5530 \& E-ISSN:0976-5549, Volume 3, Issue 2, pp.-121-126.

Copyright: Copyright@2012 Chavan L.N., et al. This is an open-access article distributed under the terms of the Creative Commons Attribution License, which permits unrestricted use, distribution, and reproduction in any medium, provided the original author and source are credited.

\section{Introduction}

Dimensional relationship between body segments \& the whole body has been the focus of scientist, anatomist and anthropologist for many years. [1] The stature is a measure of biological development and is determined by a combination of genetic and environmental factors. Foot dimensions deal with morphological features like size, shape, foot width, foot height and segmental length. Foot dimensions display a definite biologic co-relation with stature \& because of this relationship it is possible to predict the stature from foot length. This reliability was first suggested by Rutishauser[2]

Studying foot pattern and foot dimensions can reveal information regarding surgical and pathological conditions like talipes equinovarus, flat foot or varus metatarsal and other familial or acquired anomalies [3]. It also plays a vital role in medical rehabilitation, sport sciences and foot wear design[4].Foot dimensions also exhibit sexual dimorphism.

Stature is usually determined by employing mathematical or anatomical method. Main disadvantage of anatomical method is that nearly complete skeleton is needed for stature estimation. In this present study the mathematical method is utilized for stature estimation.[5]

Aim-To find out the relation between stature \& foot dimensions in school children of western Maharashtra.

\section{Objectives}

1. Document the association between stature and foot measurement among different growing age groups.

2. Formulate stature estimation equations from foot measurements for the different growing age groups.

3. Find out sexual dimorphism in foot measurements.

4. Find out bilateral differences in foot measurements and its significance.

5. Find out correlation between the variables.

\section{Material and Method}

A total no. of 200 subjects were considered for this study.

Sample1: Primary school children between 6 to 8 years

Females-48 (sample 1-a) and males - 52 (sample 1-b). 
Sample 2: Secondary school children between 12 to 14 years

Females- 51 (sample 2-a) and males -49 (sample 2-b)

Informed consent was taken from the concerned authority and the children were briefed about the procedure for their co-operation. Those who had deformed foot and history of injury were eliminated from the study. The measurements were taken at a fixed time of the day to eliminate diurnal variations.

Foot length (HTL-heel to toe length) was measured by anatomical method. In this, subjects were asked to stand in anatomical position on a white paper. Edge of a metal ruler was placed at the tip of toes (touching the pulp) and marked on the paper. 2nd point was marked at the back of the heel on its most prominent point. Foot length was measured by joining these two points at the level of each toe. Foot width (FW) was measured by taking the distance between most prominent point on the medial side (Metatarsal tibialae) and the lateral side (Metatarsal fibulae) using a vernier caliper [6] Metatarsophalangeal joint girth (MPJG) of the foot was measured using a measuring tape.[7]

Fig. 1- Foot

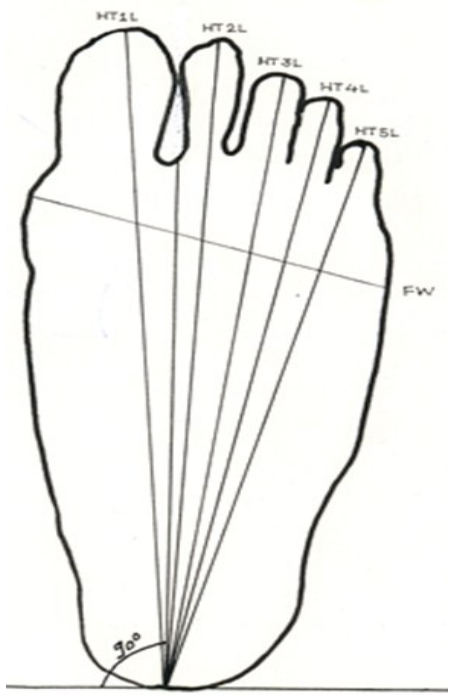

Measurement

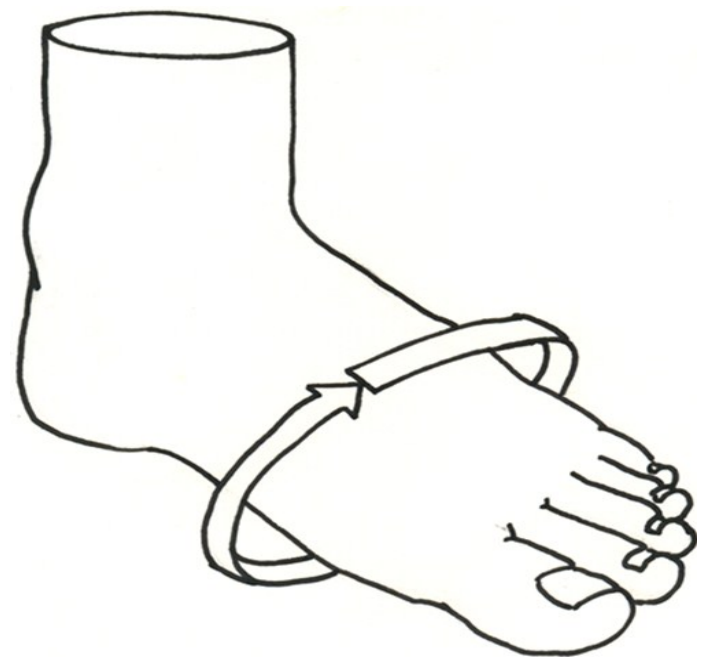

Fig. 2- Metatarso- phalangeal joint girth (MPJG)

\section{Observations, Analysis And Results}

Table1-a -Sample 1-a: Age group 6 to 8 years female

\begin{tabular}{|c|c|c|c|c|c|c|c|c|}
\hline \multirow{2}{*}{$\begin{array}{l}\text { Meas- } \\
\text { urement } \\
\text { (in } \mathrm{cm} \text { ) }\end{array}$} & \multicolumn{2}{|l|}{ Mean } & \multicolumn{2}{|c|}{$\begin{array}{l}\text { Standard } \\
\text { deviation }\end{array}$} & \multicolumn{2}{|c|}{ Minimum } & \multicolumn{2}{|c|}{ Maximum } \\
\hline & Left & Right & Left & Right & Left & Right & Left & Right \\
\hline HT1L & 17.975 & 17.956 & 1.8572 & 1.8989 & 11.5 & 11.8 & 20.7 & 20.6 \\
\hline HT2L & 17.894 & 18.050 & 1.4882 & 1.4878 & 14.2 & 14.9 & 20.4 & 21.1 \\
\hline HT3L & 17.300 & 17.415 & 1.3621 & 1.4572 & 14.2 & 14.2 & 19.7 & 20.2 \\
\hline HT4L & 16.260 & 16.454 & 1.2535 & 1.2868 & 13.5 & 13.7 & 18.5 & 18.9 \\
\hline HT5L & 14.913 & 15.171 & 1.0837 & 1.1495 & 12.5 & 13.1 & 17.1 & 17.6 \\
\hline FW & 6.733 & 6.875 & 0.4764 & 0.4679 & 5.9 & 6.0 & 7.6 & 7.8 \\
\hline MPJG & 16.958 & 16.667 & 1.8446 & 1.2604 & 14 & 14 & 23 & 20 \\
\hline $\begin{array}{l}\text { STAT- } \\
\text { URE }\end{array}$ & 119.52 & & 15.578 & & 103 & & 170 & \\
\hline
\end{tabular}

Table1-b -Sample 1-b: Age group 6 to 8 years male

\begin{tabular}{|c|c|c|c|c|c|c|c|c|}
\hline \multirow{2}{*}{$\begin{array}{l}\text { Meas- } \\
\text { urement } \\
(\text { in } \mathrm{cm} \text { ) }\end{array}$} & \multicolumn{2}{|l|}{ Mean } & \multicolumn{2}{|c|}{$\begin{array}{l}\text { Standard } \\
\text { deviation }\end{array}$} & \multicolumn{2}{|c|}{ Minimum } & \multicolumn{2}{|c|}{ Maximum } \\
\hline & Left & Right & Left & Right & Left & Right & Left & Right \\
\hline HT1L & 18.348 & 18.323 & 1.0017 & 0.9845 & 16.5 & 16.2 & 20.3 & 20.1 \\
\hline HT2L & 18.027 & 18.002 & 1.0162 & 1.0170 & 16 & 15.4 & 19.7 & 19.7 \\
\hline HT3L & 17.523 & 17.515 & 1.0977 & 1.0984 & 15.5 & 15 & 19.7 & 19.5 \\
\hline HT4L & 16.273 & 16.588 & 1.1882 & 0.9769 & 13.3 & 14.5 & 18.3 & 18.3 \\
\hline HT5L & 15.254 & 15.371 & 0.8576 & 0.9300 & 13.5 & 13.5 & 16.9 & 17 \\
\hline FW & 7.023 & 6.981 & 0.3833 & 0.6139 & 6.3 & 5.0 & 7.9 & 8.0 \\
\hline MPJG & 17.481 & 17.442 & 1.1288 & 1.4741 & 16 & 14 & 20 & 20 \\
\hline $\begin{array}{l}\text { STAT- } \\
\text { URE }\end{array}$ & 112.27 & & 8.327 & & 97 & & 127 & \\
\hline
\end{tabular}

Table1-c -Sample 2-a: Age group 12 to 14years female

\begin{tabular}{|c|c|c|c|c|c|c|c|c|}
\hline \multirow{2}{*}{$\begin{array}{l}\text { Meas- } \\
\text { urement } \\
\text { (in } \mathrm{cm} \text { ) }\end{array}$} & \multicolumn{2}{|l|}{ Mean } & \multicolumn{2}{|c|}{$\begin{array}{l}\text { Standard } \\
\text { deviation }\end{array}$} & \multicolumn{2}{|c|}{ Minimum } & \multicolumn{2}{|c|}{ Maximum } \\
\hline & Left & Right & Left & Right & Left & Right & Left & Right \\
\hline HT1L & 21.465 & 21.714 & 1.4408 & 1.5905 & 18.9 & 14.8 & 23.6 & 24.0 \\
\hline HT2L & 21.086 & 21.369 & 1.3891 & 1.2802 & 18.5 & 18.9 & 23 & 23.5 \\
\hline HT3L & 20.282 & 20.202 & 1.4722 & 1.2544 & 17.4 & 17.5 & 22.5 & 22.5 \\
\hline HT4L & 19.061 & 19.067 & 1.6929 & 1.3386 & 15.4 & 14.6 & 22.1 & 21.5 \\
\hline HT5L & 17.797 & 17.712 & 1.5583 & 1.1673 & 14.8 & 15.7 & 21.0 & 19.8 \\
\hline FW & 8.094 & 8.214 & 0.6005 & 0.5138 & 7.2 & 7.3 & 8.9 & 9.0 \\
\hline MPJG & 20.255 & 20.392 & 1.3834 & 1.2503 & 18 & 18 & 23 & 22 \\
\hline $\begin{array}{l}\text { STAT- } \\
\text { URE }\end{array}$ & 148.33 & & 7.456 & & 130 & & 162 & \\
\hline
\end{tabular}

Table1-d -Sample 2-b: Age group 12 to 14years male

\begin{tabular}{|c|c|c|c|c|c|c|c|c|}
\hline \multirow{2}{*}{$\begin{array}{l}\text { Meas- } \\
\text { urement } \\
\text { (in } \mathrm{cm} \text { ) }\end{array}$} & \multicolumn{2}{|l|}{ Mean } & \multicolumn{2}{|c|}{$\begin{array}{l}\text { Standard } \\
\text { deviation }\end{array}$} & \multicolumn{2}{|c|}{ Minimum } & \multicolumn{2}{|c|}{ Maximum } \\
\hline & Left & Right & Left & Right & Left & Right & Left & Right \\
\hline HT1L & 23.369 & 23.301 & 2.2914 & 2.1509 & 15.5 & 15.2 & 28.0 & 26.7 \\
\hline HT2L & 23.044 & 22.996 & 1.2573 & 2.0528 & 21.2 & 15.5 & 25.9 & 26.7 \\
\hline HT3L & 22.225 & 22.281 & 1.1956 & 1.3017 & 20.3 & 19.7 & 24.9 & 25.4 \\
\hline HT4L & 21.225 & 21.199 & 1.1846 & 1.3316 & 19.6 & 19 & 24.5 & 24.9 \\
\hline HT5L & 19.715 & 19.552 & 0.9549 & 1.0202 & 18 & 18 & 21.8 & 21.8 \\
\hline FW & 8.925 & 8.885 & 0.5502 & 0.4855 & 8.0 & 8.1 & 10.2 & 10.1 \\
\hline MPJG & 21.333 & 21.188 & 1.9056 & 2.1503 & 18 & 17 & 25 & 26 \\
\hline $\begin{array}{l}\text { STAT- } \\
\text { URE }\end{array}$ & 148.62 & & 9.187 & & 134 & & 167 & \\
\hline
\end{tabular}

Table [1] Displays mean, standard deviations, minimum and maximum values of stature and left and right foot measurements in different age group. 
Table- 2-a -Sample 1-a: Age group 6 to 8 years female

\begin{tabular}{lllll}
$\begin{array}{l}\text { Measurements } \\
\text { (in cm) }\end{array}$ & $\begin{array}{l}\text { Mean difference } \\
\text { (Left-Right) }\end{array}$ & $\begin{array}{l}\text { Standard } \\
\text { deviation }\end{array}$ & 't' value & $\begin{array}{l}\text { Signifi- } \\
\text { cance }\end{array}$ \\
HT1L & -0.0187 & 0.3468 & -0.375 & 0.710 \\
HT2L & 0.1562 & 0.3222 & 3.367 & $0.002^{*}$ \\
HT3L & 0.1146 & 0.6748 & 1.176 & 0.245 \\
HT4L & 0.1938 & 0.3284 & 4.088 & $0.000^{\star *}$ \\
HT5L & 0.2583 & 0.4616 & 3.877 & $0.000^{* *}$ \\
FW & -0.145 & 0.972 & -1.632 & 0.212 \\
MPJG & -0.2917 & 1.3362 & -1.512 & 0.137 \\
\hline
\end{tabular}

Table- 2-b -Sample 1-b: Age group 6 to 8 years male

\begin{tabular}{lllll}
$\begin{array}{l}\text { Measurements } \\
\text { (in cm) }\end{array}$ & $\begin{array}{l}\text { Mean difference } \\
\text { (Left-Right) }\end{array}$ & $\begin{array}{l}\text { Standard } \\
\text { deviation }\end{array}$ & 't' value & $\begin{array}{l}\text { Signif- } \\
\text { icance }\end{array}$ \\
HT1L & -0.0250 & 0.3377 & -0.534 & 0.596 \\
HT2L & -0.250 & 0.4401 & -0.410 & 0.684 \\
HT3L & -0.0077 & 0.7778 & -0.071 & 0.943 \\
HT4L & 0.3154 & 1.0494 & 2.167 & $0.035^{*}$ \\
HT5L & 0.1173 & 0.4950 & 1.709 & 0.094 \\
FW & -0.0194 & 0.532 & -0.367 & 0.729 \\
MPJG & -0.0385 & 0.7660 & -0.362 & 0.719 \\
\hline
\end{tabular}

In 6 to 8 yrs. females, heel to toe length of 2 nd, 4th, 5th toes are significantly larger on right side. But in the same age group in males the heel to toe length of only 4 th toe is significant on right side.

Table- 2-c -Sample 2-a: Age group 12 to 14 years female

\begin{tabular}{lllll}
$\begin{array}{l}\text { Measurements } \\
\text { (in cm) }\end{array}$ & $\begin{array}{l}\text { Mean difference } \\
\text { (Left-Right) }\end{array}$ & $\begin{array}{l}\text { Standard } \\
\text { deviation }\end{array}$ & 't' value & $\begin{array}{l}\text { Signifi- } \\
\text { cance }\end{array}$ \\
HT1L & 0.2490 & 0.7328 & 2.427 & $0.019^{*}$ \\
HT2L & 0.2824 & 0.7177 & 2.810 & $0.007^{* *}$ \\
HT3L & 0.0804 & 0.9875 & -0.581 & 0.564 \\
HT4L & 0.0059 & 1.0977 & 0.038 & 0.970 \\
HT5L & 0.0843 & 0.7311 & -0.824 & 0.414 \\
FW & 0.67 & 0.71 & 1.531 & 0.244 \\
MPJG & 0.1373 & 0.06934 & 1.414 & 0.164 \\
\hline
\end{tabular}

Table- 2-d - Sample 2-b: Age group 12 to 14 years male

\begin{tabular}{lllll}
$\begin{array}{l}\text { Measurements } \\
\text { (in cm) }\end{array}$ & $\begin{array}{l}\text { Mean difference } \\
\text { (Left-Right) }\end{array}$ & $\begin{array}{l}\text { Standard } \\
\text { deviation }\end{array}$ & 't' value & $\begin{array}{l}\text { Signifi- } \\
\text { cance }\end{array}$ \\
\hline HT1L & -0.0679 & 1.2229 & -0.385 & 0.702 \\
HT2L & -0.0479 & 2.0445 & -0.162 & 0.872 \\
HT3L & 0.0479 & 0.5608 & 0.592 & 0.557 \\
HT4L & -0.0333 & 0.4813 & -0.480 & 0.634 \\
HT5L & -0.1625 & 0.4190 & -2.687 & $0.010^{*}$ \\
FW & -0.072 & 0.97 & -1.52 & 0.426 \\
MPJG & -0.1458 & 1.0717 & -0.943 & 0.351 \\
\hline
\end{tabular}

Bilateral difference in heel to toe length in the age group 12 to 14 years of females are significant (at the level of 0.05 ) in 1stand 2nd toes. Right side is longer as compared to left. While in the same age group in males it is significant, only in 5th toe (at the level of 0.01 ), left being longer

Table 2 displays means, standard deviations and value of ' $\mathrm{t}$ ' of bilateral differences (left - right) in anthropometric measurements of foot.
Table- 3-a -Sexual dimorphism Sample no 3-a Age group 6 to 8 years

\begin{tabular}{llll|} 
& \multicolumn{3}{c}{$\mathrm{t}$ - test for Equality of Means $(95 \%$ Confi. ) } \\
\hline Foot Width R & $\mathrm{T}$ & df & Sig. (2-tailed) \\
Foot Width L & -.963 & 98 & 338 \\
MPJGRF & -3.363 & 98 & $001^{*}$. \\
MPJGLF & -2.817 & 98 & $006^{*}$ \\
HT1LRF & -1.723 & 98 & 088 \\
HT1LLF & -1.226 & 98 & 223 \\
HT2LRF & -1.263 & 98 & .209 \\
HT2LLF & .190 & 98 & .850 \\
HT3LRF & -.526 & 98 & .600 \\
HT3LLF & -.393 & 98 & .695 \\
HT4LRF & -.905 & 98 & .368 \\
HT4LLF & -.591 & 98 & .556 \\
HT5LRF & -.052 & 98 & .959 \\
HT5LLF & -.961 & 98 & .339 \\
\hline
\end{tabular}

Table- 3-b -Sexual dimorphism Sample no 3-b Age group 6 to 8 years

\begin{tabular}{llll|} 
& \multicolumn{3}{c}{$\begin{array}{c}\text { t-test for Equality of Means } \\
\text { (95\% Confi.) } \\
\text { Sig. (2-tailed) }\end{array}$} \\
\hline Foot Width R & -6.676 & 97 & $0.000^{*}$ \\
Foot Width L & -7.165 & 97 & $0.000^{*}$ \\
MPJGRF & -2.266 & 97 & 0.26 \\
MPJGLF & -3.236 & 97 & $0.02^{\star}$ \\
HT1LRF & -4.191 & 97 & $0.000^{*}$ \\
HT1LLF & -4.980 & 97 & $0.000^{*}$ \\
HT2LRF & -4.762 & 97 & $0.000^{*}$ \\
HT2LLF & -7.336 & 97 & $0.000^{*}$ \\
HT3LRF & -8.094 & 97 & $0.000^{*}$ \\
HT3LLF & -7.211 & 97 & $0.000^{*}$ \\
HT4LRF & -7.914 & 97 & $0.000^{*}$ \\
HT4LLF & -7.327 & 97 & $0.000^{*}$ \\
HT5LRF & -8.331 & 97 & $0.000^{*}$ \\
HT5LLF & -7.331 & 97 & $0.000^{*}$ \\
\hline
\end{tabular}

Table- 3- c -Sexual dimorphism Sample no 3-c Age group 6 to 8 years

\begin{tabular}{llll|} 
& \multicolumn{3}{c}{ t-test for Equality of Means $(95 \%$ Confi. ) } \\
& T & df & Sig. (2-tailed) \\
\hline Foot Width R & -6.676 & 97 & $0.000^{*}$ \\
Foot Width L & -7.165 & 97 & $0.000^{*}$ \\
MPJGRF & -2.266 & 97 & 0.26 \\
MPJGLF & -3.236 & 97 & 0.02 \\
HT1LRF & -4.191 & 97 & $0.000^{*}$ \\
HT1LLF & -4.980 & 97 & $0.000^{*}$ \\
HT2LRF & -4.762 & 97 & $0.000^{*}$ \\
HT2LLF & -7.336 & 97 & $0.000^{*}$ \\
HT3LRF & -8.094 & 97 & $0.000^{*}$ \\
HT3LLF & -7.211 & 97 & $0.000^{*}$ \\
HT4LRF & -7.914 & 97 & $0.000^{*}$ \\
HT4LLF & -7.327 & 97 & $0.000^{*}$ \\
HT5LRF & -8.331 & 97 & $0.000^{*}$ \\
HT5LLF & -7.331 & 97 & $0.000^{*}$ \\
\hline
\end{tabular}

Table 3 displays sexual dimorphism in various foot measurements 
Table- 4-a -Sample 1-a: Age group 6 to 8 years female

\begin{tabular}{|c|c|c|c|c|}
\hline $\begin{array}{l}\text { Measurements } \\
\text { (in } \mathrm{cm} \text { ) }\end{array}$ & $\begin{array}{l}\text { Left foot/ } \\
\text { stature }\end{array}$ & Significance & $\begin{array}{l}\text { Right foot I } \\
\text { stature }\end{array}$ & Significance \\
\hline HT1L & 0.281 & 0.053 & 0.266 & 0.068 \\
\hline HT2L & 0.297 & $0.040^{*}$ & 0.322 & 0.053 \\
\hline HT3L & 0.281 & 0.053 & 0.285 & 0.050 \\
\hline HT4L & 0.295 & $0.042^{*}$ & 0.385 & $0.007^{\star *}$ \\
\hline HT5L & 0.232 & 0.112 & 0.410 & $0.004^{* *}$ \\
\hline FW & 0.189 & 0.198 & 0.079 & 0.594 \\
\hline MPJG & -0.030 & 0.842 & 0.105 & 0.476 \\
\hline
\end{tabular}

Table- 4-b -Sample 1-b: Age group 6 to 8 years male

\begin{tabular}{|lllll|}
$\begin{array}{l}\text { Measurements } \\
\text { (in cm) }\end{array}$ & $\begin{array}{l}\text { Left foot/ } \\
\text { stature }\end{array}$ & Significance & $\begin{array}{l}\text { Right foot / } \\
\text { stature }\end{array}$ & Significance \\
\hline HT1L & 0.824 & $0.000^{* *}$ & 0.848 & $0.000^{* *}$ \\
HT2L & 0.844 & $0.000^{* *}$ & 0.848 & $0.000^{* *}$ \\
HT3L & 0.724 & $0.000^{* *}$ & 0.808 & $0.000^{* *}$ \\
HT4L & 0.480 & $0.000^{* *}$ & 0.818 & $0.000^{* *}$ \\
HT5L & 0.781 & $0.000^{* *}$ & 0.763 & $0.000^{* *}$ \\
FW & 0.486 & $0.000^{* *}$ & 0.390 & $0.004^{* *}$ \\
MPJG & 0.618 & $0.000^{* *}$ & 0.570 & $0.000^{* *}$ \\
\hline
\end{tabular}

1. In females of 6 to 8 years age group correlation coefficients of foot length and stature are statistically significant on both sides. HTL of right 2 nd and 4 th toe is significant (at the level of 0.05 ). HTL of left 4 th and 5 th toe is highly significant (at the level of 0.01).

2. In males of 6 to 8 years correlation coefficients of all foot measurements and stature are statistically highly significant on both sides at the level of 0.01 .

Table- 4-c -Sample 2-a : Age group 12 to 14 years female

\begin{tabular}{|c|c|c|c|c|}
\hline $\begin{array}{l}\text { Measurements } \\
\text { ( in } \mathrm{cm} \text { ) }\end{array}$ & $\begin{array}{l}\text { Left foot/ } \\
\text { stature }\end{array}$ & Significance & $\begin{array}{l}\text { Right foot I } \\
\text { stature }\end{array}$ & Significance \\
\hline HT1L & 0.010 & 0.944 & 0.093 & 0.515 \\
\hline HT2L & -0.044 & 0.757 & 0.032 & 0.822 \\
\hline HT3L & 0.014 & 0.920 & 0.053 & 0.711 \\
\hline HT4L & -0.009 & 0.951 & 0.242 & 0.088 \\
\hline HT5L & -0.102 & 0.476 & 0.096 & 0.505 \\
\hline FW & 0.241 & 0.089 & 0.328 & $0.019^{*}$ \\
\hline MPJG & 0.376 & $0.007^{\star}$ & 0.247 & 0.080 \\
\hline
\end{tabular}

Table- 4-d -Sample 2-a: Age group 12 to 14 years male

\begin{tabular}{|c|c|c|c|c|}
\hline $\begin{array}{l}\text { Measurements } \\
\text { (in } \mathrm{cm} \text { ) }\end{array}$ & $\begin{array}{l}\text { Left foot/ } \\
\text { stature }\end{array}$ & Significance & $\begin{array}{l}\text { Right foot I } \\
\text { stature }\end{array}$ & Significance \\
\hline HT1L & 0.569 & $0.000^{* *}$ & 0.568 & $0.000^{* *}$ \\
\hline HT2L & 0.146 & 0.321 & 0.601 & $0.000^{* *}$ \\
\hline HT3L & 0.549 & $0.000^{* *}$ & 0.604 & $0.000^{* *}$ \\
\hline HT4L & 0.551 & $0.000^{* *}$ & 0.649 & $0.000^{* *}$ \\
\hline HT5L & 0.527 & $0.000^{* *}$ & 0.616 & $0.000^{* *}$ \\
\hline FW & 0.596 & $0.000^{* *}$ & 0.602 & $0.000^{* *}$ \\
\hline MPJG & 0.163 & 0.269 & 0.266 & 0.067 \\
\hline
\end{tabular}

1. In females of 12 to 14 years group correlation coefficients of foot measurements and stature are statistically not significant. Only left side MPJG is highly significant at the level of 0.01 .

2. In males of 12 to 14 years group correlation coefficients of foot measurements and stature are statistically significant on both sides at the level of 0.01 . Only MPJG and HT2LLF are not significant.

Table 4- displays correlation coefficients of various foot measurements with stature.
Table- 5-a -Sample 1-a: Age group 6 to 8 years female

\begin{tabular}{lllll|}
$\begin{array}{l}\text { Measure- } \\
\text { ments (in } \\
\mathrm{cm})\end{array}$ & $\begin{array}{l}\text { Regression equation } \\
\text { for left foot }\end{array}$ & $\begin{array}{l}\text { Mean } \\
\text { error }\end{array}$ & $\begin{array}{l}\text { Regression equation } \\
\text { for right foot }\end{array}$ & $\begin{array}{l}\text { Mean } \\
\text { error }\end{array}$ \\
\hline HT1L & $77.084+(2.361 \times$ HTIL) & 15.110 & $\begin{array}{l}80.352+ \\
(2.181 \times \text { HT1LR })\end{array}$ & 15.180 \\
HT2L & $63.830+(3.112 \times$ HT2L) & $15.035^{*}$ & $58.756+(3.366 \times$ HT2L) & $14.911^{*}$ \\
HT3L & $63.931+(3.213 \times$ HT3L) & 15.112 & $66.520+(3.043 \times$ HT3L) & 15.095 \\
HT4L & $59.990+(3.661 \times$ HT4L) & $15.048^{*}$ & $42.821+(4.661 \times$ HT4L) & $14.533^{*}$ \\
HT5L & $69.728+(3.339 \times$ HT5L) & 15.316 & $35.230+(5.556 \times$ HT5L) & $14.363^{*}$ \\
FW & $77.879+(6.184$ FWL) & 4.734 & $101.465+(2.626$ FWR $)$ & 4.894 \\
MPJG & $123.758+(-0.250 \times$ MPJG) & 15.740 & $97.795+(1.304 \times$ MPJG $)$ & 15.659 \\
\hline
\end{tabular}

Table- 5-b -Sample 1-b: Age group 6 to 8 years male

\begin{tabular}{|c|c|c|c|c|}
\hline $\begin{array}{l}\text { Meas- } \\
\text { urement } \\
\mathbf{s}(\text { in } \mathrm{cm})\end{array}$ & $\begin{array}{l}\text { Regression equation } \\
\text { for left foot }\end{array}$ & $\begin{array}{l}\text { Mean } \\
\text { error }\end{array}$ & $\begin{array}{l}\text { Regression equation } \\
\text { for right foot }\end{array}$ & $\begin{array}{l}\text { Mean } \\
\text { Error }\end{array}$ \\
\hline HT1L & $-13.348+(6.846 \times H T 1 L)$ & $4.770^{* *}$ & $-19.088+(7.169 \times \mathrm{HT} 1 \mathrm{~L})$ & $4.463^{*}$ \\
\hline HT2L & $-12.340+(6.912 \times \mathrm{HT} 2 \mathrm{~L})$ & $4.517^{* *}$ & $-12.661+(6.940 \times \mathrm{HT} 2 \mathrm{~L})$ & $4.463^{*}$ \\
\hline HT3L & $15.981+(5.495 \times \mathrm{HT} 3 \mathrm{~L})$ & $5.798^{* *}$ & $4.679+(6.143 \times H T 3 L)$ & $4.959^{*}$ \\
\hline HT4L & $57.535+(3.363 \times \mathrm{HT} 4 \mathrm{~L})$ & $7.378^{* *}$ & $-3.390+(6.975 \times H T 4 L)$ & $4.838^{*}$ \\
\hline HT5L & $-3.366+(7.581 \times$ HT5L) & $5.255^{* *}$ & $7.265+(6.831 \times \mathrm{HT} 5 \mathrm{~L})$ & $5.437^{*}$ \\
\hline FW & $30.051+(10.568) \mathrm{FWL}$ & $2.684^{* *}$ & $75.380+(5.284$ FWR $)$ & $1.767^{* *}$ \\
\hline MPJG & $32.569+(4.559 \times \mathrm{MPJG})$ & $6.611^{* *}$ & $56.114+(3.220 \times \mathrm{MPJG})$ & $6.910^{*}$ \\
\hline
\end{tabular}

In sample 1, Only FL is significant for calculation of stature.

But in males of this age group FL, FW and MPJG all are highly significant.

Table- 5-c -Sample 2-a: Age group12 to 14years female

\begin{tabular}{|c|c|c|c|c|}
\hline $\begin{array}{l}\text { Measure- } \\
\text { ments (in } \\
\mathrm{cm} \text { ) }\end{array}$ & $\begin{array}{l}\text { Regression equation } \\
\text { for left foot }\end{array}$ & $\begin{array}{l}\text { Mean } \\
\text { error }\end{array}$ & $\begin{array}{l}\text { Regression equation } \\
\text { for right foot }\end{array}$ & $\begin{array}{l}\text { Mean } \\
\text { error }\end{array}$ \\
\hline HT1L & 147.217+(0.052×HT1L) & 7.531 & 138.845+(0.437×HT1L) & 7.499 \\
\hline HT2L & $153.353+(-0.238 \times \mathrm{HTTL})$ & 7.524 & $144.309+(0.188 \times \mathrm{HT} 2 \mathrm{~L})$ & 7.527 \\
\hline HT3L & $146.855+(0.073 \times \mathrm{HT} 3 \mathrm{~L})$ & 7.531 & $141.948+(0.316 \times \mathrm{HT} 3 \mathrm{~L})$ & 7.521 \\
\hline HT4L & $149.069+(-0.039 \times \mathrm{HT} 4 \mathrm{~L})$ & 7.531 & $122.675+(1.346 \times \mathrm{HT} 4 \mathrm{~L})$ & 7.308 \\
\hline HT5L & $157.015+(-0.488 \times \mathrm{HTTL})$ & 7.492 & $137.519+(0.611 \times \mathrm{HT} 5 \mathrm{~L})$ & 7.497 \\
\hline FW & $124.134+(2.990 \quad \mathrm{FWL})$ & 1.722 & $109.278+(4.755 \quad F W R)$ & 1.958 \\
\hline MPJG & 107.338+(2.024×MPJG) & $6.980^{*}$ & 118.241+(1.476×MPJG) & 7.297 \\
\hline
\end{tabular}

Table- 5-d -Sample 2-b: Age group 12 to 14 years male

\begin{tabular}{|c|c|c|c|c|}
\hline $\begin{array}{l}\text { Meas- } \\
\text { urement } \\
\mathbf{s} \text { (in } \mathrm{cm} \text { ) }\end{array}$ & $\begin{array}{l}\text { Regression equation } \\
\text { for left foot }\end{array}$ & $\begin{array}{l}\text { Mean } \\
\text { error }\end{array}$ & $\begin{array}{l}\text { Regression equation } \\
\text { for right foot }\end{array}$ & $\begin{array}{l}\text { Mean } \\
\text { error }\end{array}$ \\
\hline HT1L & $95.356+(2.279 \times \mathrm{HT} 1 \mathrm{~L})^{* \star}$ & 7.640 & $92.064+(2.427 \times \mathrm{HT} 1 \mathrm{~L})$ & $7.641^{* \star}$ \\
\hline HT2L & $123.976+(1.070 \times \mathrm{HT} 2 \mathrm{~L})$ & 9.187 & $86.819+(2.688 \times \mathrm{HT} 2 \mathrm{~L})$ & $7.426^{\star *}$ \\
\hline HT3L & $54.876+(4.217 \times \mathrm{HT} 3 \mathrm{~L})^{* *}$ & 7.764 & $53.616+(4.264 \times \mathrm{HT} 3 \mathrm{~L})$ & $7.401^{* *}$ \\
\hline HT4L & $57.852+(4.277 \times \mathrm{HT} 4 \mathrm{~L})^{\star *}$ & 7.747 & $53.686+(4.480 \times \mathrm{HT} 4 \mathrm{~L})$ & $7.063^{* \star}$ \\
\hline HT5L & $48.735+(5.067 \times \mathrm{HT} 5 \mathrm{~L})^{* *}$ & 7.895 & $40.138+(5.549 \times \mathrm{HT} 5 \mathrm{~L})$ & $7.315^{\star \star}$ \\
\hline FW & $59.783+(9.954 \mathrm{FWL})$ & 1.977 & 47.389+(11.393 FWR) & 2.228 \\
\hline MPJG & $131.875+(0.785 \times M P J G)$ & 9.163 & $124.506+(1.138 \times M P J G)$ & 8.951 \\
\hline
\end{tabular}

In sample 2, in age group 12 to $14 \mathrm{yrs}$. estimation of stature from $\mathrm{FL}$ is significant in males. But in females of this age group it is not significant.

Table 5: displays regression equations for estimation of stature through various length-breadth measurements of foot.

\section{Discussion}

The estimation of stature from various long bones, head length \& hand length has been attempted by many workers. However, foot 
dimensions have not frequently been used for this.

The present study uses mathematical method (division factors \& regression analysis) to determine the stature from foot dimensions. The regression analysis gives better reliability of estimate in prediction of stature than the division factor

method [1]

Given study deals with the correlation of total standing height with different foot measurements in students of western Maharashtra in three different age groups.

\section{Sample No 1 age group 6 to 8 years}

As seen in table No 2-a and b, HTL of 2nd, 4th and 5th toes is significantly more on right side in females. But in the same age group in males the HTL of only right side is more. Sexual dimorphism is not significant statistically in this age group.

Correlation coefficient between stature and HTL of 2nd, 3rd and 4th toes on left side is statistically significant in females. While in males it is significant with HTL of right 4th toe. Regression equations for estimation of stature through various foot dimensions are seen in table no.5. The regression equation using HTL of 2 nd and 4 th toes on both sides in female is significant statistically. And in males all parameters are significant statistically.

\section{Sample No.2 age group 12 to 14 years.}

As seen in table no.2- $c$ and d, the HTL of right 1 st and 2 nd toes is statistically more in females. And HTL of left 5th toe is more in males.

Sexual dimorphism in majority of the measurements is statistically significant, values being more in males.

Correlation coefficients of various foot measurements with stature are seen in table no.4. Correlation coefficients for all parameters are highly significant statistically on both sides in males except HTL of left 2nd toe and MPJG of both sides. In females it is significant only with right foot width and left MPJG.

In males all regression equations using $\mathrm{FL}$ are highly significant but FW \& MPJG of both sides is insignificant. And in females only left side MPJG is significant in calculation of stature.
The mean error was always less than 0.01 for any measurement in any given age group. So this shows that estimation of stature can be done with different measurements, more so with FL and FB. This study is comparable with similar such studies done by Sen Jaydip et al 2008 [8]and Patel S.M. et al 2007 [9].

\section{Conclusion}

It is worthwhile to mention here that the present study is a pioneering study in forensic anthropology to correlate between foot dimensions \& the stature in western Maharashtra. The study result showed a significant relationship between these two parameters. Sexual dimorphisms as well as bilateral differences in various foot measurements are also seen.

\section{References}

[1] Isurani llayperuma, Ganananda Nanayakkara, Nadeeka Palahepitiya (2009) Galle Medical Journal.14(1), 15-17.

[2] Ingrid H.E. Rutishauser (1968) Prediction of height from foot length use of measurement in field survey Arch. Dis. Child, 43, 310.

[3] Grivas T.B. (1987) Estimation of foot length in children 2-12 years old in Athenes, 51, 501-506.

[4] Delsinger, Breining J.R., .Rler(2000) A. Virtual environment.

[5] Manisha R. Dayal, Marayna Steyn, Kevin L. Kuykendall (2008) Journal of Sciences, 104, 124-129.

[6] Krishan Kewal (2008) Am J. forensic med Pathol, 29(4), 297303.

[7] Agic Ante, Nikolic Vasilije and Mijovir Budimir (2006) Foot Anthropometry and Morphology Phenomena. Coll. Antropol, 30(4), 815 - 821.

[8] Sen Jaydip, Shila Ghosh (2008) Forensic science international J., 181: $55 \mathrm{el}-55$ e6.

[9] Patel S.M., Shah S.V., Patel G.V. (2008) J. Anat Soc, India, 56(1), 25- 27.

Table- 6-a -Sample1-a: Age group 6 to 8 years female

Mequation:

1) Multiple regression equation for right foot

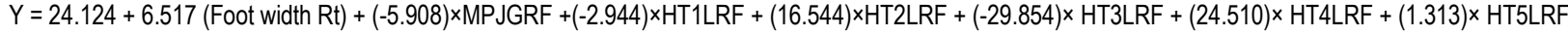

2) Multiple regression equation for left foot:

$\mathrm{Y}=81.439+(6.554) \times$ Foot width Lt + (-4.976) $\times$ MPJGLF + (-2.790) xHT1LLF + (1.055) $\times H T 2 L L F+(6.928) \times H T 3 L L F+(12.779) \times H T 4 L L F+(-14.622) \times H T 5 L L F$

Table- 6-b -Sample1-b: Age group 6 to 8 years male

Mequation:

1) Multiple regression equation for right foot :

$Y=(-19.424)+(-2.359) \times$ Foot width Rt + $(-0.233) \times$ MPJGR +(3.920) $\times$ HT1LRF + (2.482) $\times H T 2 L R F+(1.215) \times H T 3 L R F+(-0.093) \times H T 4 L R F+(1.039) \times H T 5 L R F$

2) Multiple regression equation for left foot :

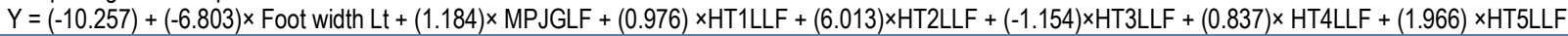

1. In age group of 6 to 8 years female using right foot measurements percentage of dependency of these factor on estimated stature is $40 \%$

2. In age group of 6 to 8 years female using left foot measurements percentage of dependency of these factor on estimated stature is 
$22 \%$

3. In age group of 6 to 8 years male using right foot measurements percentage of dependency of these factor on estimated stature is $76 \%$

4. In age group of 6 to 8 years male using left foot measurements percentage of dependency of these factor on estimated stature is $76 \%$

Table- 6-c -Sample2-a: Age group 12 to 14years female

\section{Mequation:}

1) Multiple regression equation for right foot:

$\mathrm{Y}=(73.267)+(4.960) \times$ Foot width Rt $+(0.604) \times \mathrm{MPJGRF}+(1.240) \times \mathrm{HT} 1 \mathrm{LRF}+(-0.727) \times \mathrm{HT} 2 \mathrm{LRF}+(0.374) \times \mathrm{HT} 3 \mathrm{LRF}+(3.358) \times \mathrm{HT} 4 \mathrm{LRF}+(-3.442) \times \mathrm{HT} 5 \mathrm{LRF}$

2) Multiple regression equation for left foot

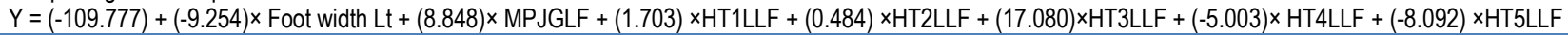

Table- 6-d -Sample 2-b: Age group 12 to 14 years male

\section{Mequation:}

1) Multiple regression equation for right foot:

$Y=(5.084)+(7.232) \times$ Foot width Rt $+(-0.639) \times$ MPJGRF + (-2.084) $\times$ HT1LRF + (3.368) $\times H T 2 L R F+(1.122) \times H T 3 L R F+(-0.807) \times H T 4 L R F+(2.869) \times H T 5 L R F$

2) Multiple regression equation for left foot

$Y=(57.128)+(7.425) \times$ Foot width Lt + (-0.745) $\times$ MPJGLF + (1.144) $\times H T 1 L L F+(-1.073) \times H T 2 L L F+(1.026) \times H T 3 L L F+(0.220) \times H T 4 L L F+(0.590) \times H T 5 L L F$

1. In age group of 12 to 14 years female using right foot measurements percentage of dependency of these factor on estimated stature is $25 \%$

2. In age group of 12 to 14 years female using left foot measurements percentage of dependency of these factor on estimated stature is $66 \%$

3. In age group of 12 to 14 years male using right foot measurements percentage of dependency of these factor on estimated stature is $58 \%$

4. In age group of 12 to 14 years male using left foot measurements percentage of dependency of these factor on estimated stature is $50 \%$

Table 6- displays the multiple regression equations for estimation of stature using all the parameters and its accuracy is predicted 